either with etanercept (ETA, $10 \mathrm{mg} / \mathrm{kg}$ ), an anti-mouse TNF antibody (MP6-XT22, rat IgG1, $10 \mathrm{mg} / \mathrm{kg}$ ) or an anti-human IL17 antibody (secukinumab, SEC, $10 \mathrm{mg} / \mathrm{kg}$ ) as a control. Daily clinical evaluation of $\mathrm{K} / \mathrm{BxN}$ serum induced-arthritis was performed in 3TG as well as WT mice. Polarization of bone marrow-derived macrophages (BMDM) and cytokine production from non-arthritic WT and 3TG mice under the action of antiTNF in vitro was evaluated by RT-qPCR, CBA and ELISA.

Results In vivo, the administration of anti-TNF (ETA or MP6XT22) decreased arthritic scores in WT mice $(p=0.005)$ as well as in 3TG mice $(p<0.001)$, unlike SEC which had no effect, proving that anti-TNF binding of tmTNF decreased arthritis. In vitro effect of anti-TNF on BMDM from WT as well as 3TG mice induced a decrease in the expression of genes specific of inflammatory macrophages (CD38, GpR18 and FpR2), and an increase in the expression of genes specific of alternative macrophages (Arg1, EgR2, c-Myc). We also observed an inhibition of the secretion of pro-inflammatory cytokines (IL12p70 and IL-6) and an early peak of IL-10 secretion demonstrating an effect of reverse signaling on macrophage polarization and activation. This suggested a switch in macrophage polarization as a probable mechanism for modulation of inflammation during $\mathrm{K} / \mathrm{BxN}$ serum-induced arthritis.

Conclusions Our work provides in vivo evidence for the involvement of reverse signaling in the anti-TNF-mediated modulation of arthritis. Reverse signaling is expected to result in the modulation of macrophage polarization from an inflammatory to an alternative functional phenotype in arthritic mice. Our data prompt us to consider new interpretation of the effects of anti-TNF in the treatment of RA.

Disclosure of Interest None declared.

\section{P039/003 CIRCULATING FOLLICULAR HELPER T CELLS ARE INCREASED IN SYSTEMIC SCLEROSIS AND PROMOTE PLASMABLAST DIFFERENTIATION THROUGH THE IL-21 PATHWAY WHICH CAN BE INHIBITED BY RUXOLITINIB}

${ }^{1} \mathrm{~L}$ Ricard*, ${ }^{1} \mathrm{~V}$ Jachiet, ${ }^{2} \mathrm{~F}$ Malard, ${ }^{1} \mathrm{Y} Y \mathrm{Y},{ }^{1} \mathrm{~N}$ Stocker, ${ }^{3} \mathrm{~S}$ Rivière, ${ }^{4} \mathrm{P}$ Senet, ${ }^{4} \mathrm{~J}-\mathrm{B}$ Monfort, ${ }^{3} \mathrm{O}$ Fain, ${ }^{2} \mathrm{M}$ Mohty, ${ }^{1} \mathrm{~B}$ Gaugler, ${ }^{3} \mathrm{~A}$ Mekinian. ${ }^{1}$ Centre de recherche Saint-Antoine, INSERM; ${ }^{2}$ Hématologie; ${ }^{3}$ Médecine Interne, Hôpital Saint-Antoine; ${ }^{4}$ Dermatologie, Hôpital Tenon, Paris, France

\subsection{6/annrheumdis-2018-EWRR2019.31}

Career situation of first and presenting author Student for a master or a $\mathrm{PhD}$

Introduction Systemic sclerosis (SSc) is an autoimmune disease characterized by widespread fibrosis, microangiopathy and autoantibodies. Follicular helper $\mathrm{T}$ (Tfh) cells $\mathrm{CD} 4{ }^{+} \mathrm{CXCR} 5{ }^{+} \mathrm{PD}-1^{+}$cooperate with $\mathrm{B}$ lymphocytes to induce the differentiation of plasmocytes secreting Immunoglobulins (Ig). Circulating Tfh (cTfh) cells are increased in several autoimmune diseases. ${ }^{1}$ Tfh cells can infiltrate the skin of SSc patients, and induce fibrosis in vitro. ${ }^{2}$

Objectives The aim of this study was to perform a quantitative and functional analysis of cTfh cells in SSc.

Methods Using flow cytometry, we analyzed cTfh cells from 52 SSc patients with no immodulotary treatment and 38 healthy controls (HC). In vitro coculture experiments of sorted cTfh and B cells from 13 SSc patients and $6 \mathrm{HC}$ were performed for functional analysis. $\operatorname{IgG}$ and $\operatorname{IgM}$ production were measured by ELISA. BCL-6, Blimp-1, CXCL13 and IL21 expression were analyzed by RTqPCR.
Results We observed that cTfh cell numbers are increased in SSc patients compared with HC. Furthermore, the increase in cTfh cells was more potent in patients with severe forms of SSc such as diffuse SSc and in the presence of arterial pulmonary hypertension. cTfh cells from SSc patients present an activated Tfh phenotype, with high expression of BCL-6 and increased capacity to produce IL-21 in comparison to HC. In vitro, cTfh cells from SSc patients had higher capacity to stimulate the differentiation of $\mathrm{CD} 19^{+} \mathrm{CD} 27^{+} \mathrm{CD} 38^{\text {hi }} \mathrm{B}$ cells and their secretion of $\operatorname{IgG}$ and $\operatorname{IgM}$ through the IL-21 pathway than cTfh cells from HC. Blocking IL-21 or using the JAK1/2 inhibitor ruxolitinib reduced the Tfh cells' capacity to stimulate the plasmablasts and Ig production.

Conclusions Circulating Tfh cells are increased in SSc and correlate with SSc severity. The IL-21 pathway or JAK1/2 blockade by ruxolitinib could be a promising strategy in the treatment of SSc.

\section{REFERENCES}

1. Crotty S. T follicular helper cell differentiation, function, and roles in disease. Immunity 2014;41(4):529-42.

2. Taylor DK, Mittereder N, Kuta E, Delaney T, Burwell T, Dacosta K, et al. T follicular helper-like cells contribute to skin fibrosis. Sci Transl Med 2018;10(431).

Acknowledgements This work was supported by the Aterhit foundation and received grants from 'Groupe Francophone de Recherche sur la Sclérodermie' (GFRS).

Disclosure of Interest None declared

\section{P040 THE EUROPEAN CONSENSUS FINDING STUDY GROUP ON AUTOANTIBODIES 2017/18 INVESTIGATION. CHARACTERISATION OF AUTOANTIBODY CONTENT IN A NEW INTERNATIONAL REFERENCE STANDARD FOR DENSE FINE SPECKLED 70KD (DFS70) AUTOANTIBODIES}

1J Rönnelid*, ${ }^{2} \mathrm{M}$ Blüthner, ${ }^{3} \mathrm{C}$ Dahle, ${ }^{4} \mathrm{~L}$ Andrade, ${ }^{5} \mathrm{E}$ Feist, ${ }^{6} \mathrm{D}$ Hamann, on behalf of The European Consensus Finding Study Group on autoantibodies (ECFSG)*. 'Uppsala Univ, Dept Immunol, Genet and Pathol, Uppsala, Sweden; 'Laboratory Volkmann, Karlsruhe, Germany; ${ }^{3}$ Linköping Univ, Dept Clin Exp Med, Linköping, Sweden; ${ }^{4}$ Dept Rheumatol, São Paulo Univ, São Paulo, Brazil; ${ }^{5}$ Charité, Dept Rheumatol Clin Immunol, Berlin, Germany; ${ }^{6}$ Utrecht Univ, LTI Diagnostics, Utrecht, Netherlands

\subsection{6/annrheumdis-2018-EWRR2019.32}

Career situation of first and presenting author Instructor.

Introduction The European Consensus Finding Study Group on autoantibodies (ECFSG) a.k.a. the EULAR autoantibody study group has been active for 30 years.

Objectives To reach consensus about autoantibody measurements in clinical practice, and to evaluate upcoming autoantibody standard reagents concerning autoantibody content.

Methods ECFSG focus on evaluating difficult to interpret serum samples, where differences between assays can be clearly visible. Ten unknown samples are distributed yearly to European laboratories, and analyzed broadly. Results are collected with information about laboratory techniques used, and discussed in relation to clinical information on the donating patients during EWRR. The 2017/2018 investigation contained nine patient samples, and a not yet launched pooled standard for anti-dense fine speckled $70 \mathrm{kD}$ antibodies, an ANA reactivity with specific nuclear staining on HEp-2 cells that can be confounded with homogenous ANA, but that is not associated with autoimmune disease.

Results Acceptable consensus was reached for the clinical samples. Anti-DFS70 pattern was reported from 32/38 
laboratories, whereas 5/38 reported homogenous ANA, one reported unknown pattern. Except for 4 out of 24 laboratories reporting anti-histone and 2 out of 33 laboratories reporting ACPA, both in low levels, no autoantibodies were reported. Consensus was that the sample contained pure antiDFS70.

Conclusions ECFSG helps to keep awareness on differences between autoantibody assays. The anti-DFS70 ANA pattern was identified by most laboratories in a reagent that proved to be free of other autoantibodies. The anti-DFS70 standard will be available via http://asc.dental.ufl.edu/ReferenceSera. html\#text.

"Lab representatives: Renaudineau Y, Brest; Fricke M, Hannover; Shoenfeld Y, Sheba, Israel; Nozal Aranda P, Madrid; Tzioufas AG, Athens; Kozakova D, Piestany; Toubi E, Haifa, Israel; Franceschini F, Brescia; Hennessy L, Glasgow; Roux-Lombard P, Genève; Heijnen I, Basel; Karlsen R, Oslo; Jeremie W, Luxembourg; Bombardieri S, Pisa; Cucnik S, Ljubljana; Huber AR, Aarau; Roozendal C, Groningen; Goetz J, Strasbourg; Vencovsky J, Praha; Wojciechowska B, Warsaw; Guerti K, Antwerp; Hänninen A, Turku; McHugh N, Bath; Steiner G Wien; Schreurs M, Rotterdam; Montes Cano MA, Sevilla; Elvin K, Stockholm; Nagy E, Budapest; Babai I, Tikva, Israel; Bonroy C, Gent; Burmester GR, Berlin; Andrejevic S, Belgrade; Kral V, Usti nad Labem; Csernok E, Tübingen; Probst-Mueller E, Zürich; Fischer K, Szczecin; Hacein-BeyAbina S, Paris; Conrad K, Dresden; Humbel RL, Leudelange. Disclosure of Interest None declared.

\section{\begin{tabular}{|l|l}
\hline P041 IMMUNOLOGICAL CHARACTERISTICS AND \\
\hline
\end{tabular} DISTRIBUTION OF CRYOGLOBULINS IN A COHORT OF 13000 PATIENTS OVER 6 YEARS}

1,2MN Sarda* ${ }^{1,3} \mathrm{P}$ Miossec. 'Immunogenomics and inflammation research Unit EA 4130, Lyon 1 University; ${ }^{2}$ Immunology Laboratory; ${ }^{3}$ Dpt of Immunology and Rheumatology, Clinical Immunology Unit, Hospices Civils de Lyon, LYON, France

\subsection{6/annrheumdis-2018-EWRR2019.33}

Career situation of first and presenting author Assistant.

Introduction Cryoglobulins (CG) are immunoglobulins (Ig) that precipitate in vitro at cold temperature and dissolve at $37^{\circ} \mathrm{C}$, they are classified in 3 types. Type I CG are monoclonal Ig of IgM or IgG isotype. Type II and III are mixed CG: type II CG associate a monoclonal with polyclonal Ig, type III CG associate polyclonal Ig. Rheumatoid factor activity (RF) of mixed CG leads to the formation of immune complexes that can precipitate and result in vasculitis.

Objectives The purpose of this study was to update information on CG biological characteristics in a large population recruited from all clinical departments of a French University Hospital.

Methods This retrospective study was conducted from January 2010 to December 2016. Patients included had at least one serum sample for CG detection and characterization: CG isotype and clonality, concentration and RF (IgM anti-IgG) in the cryoprecipitate; and serum complement exploration. Associated pathologies were determined by biological markers of gammopathy, viral infection and autoimmunity.

Results A total of 13439 patients were included, 1675 $(12,5 \%)$ of whom had positive CG. In case of negative CG detection, 2213 patients were retested and CG was detected on the new sample for $196 / 2213$ patients (8.9\%). Type I CG was found in $9.3 \%(155 / 1675)$, type II CG in $47 \%(788 /$
1675), and type III CG in $43.7 \%(732 / 1675)$ of patients. In type I CG, IgM CG was more frequent than IgG CG, but in lower concentration $(p=0.02)$. For mixed CG, 34.8\% of HCV + tested patients had CG, less than 5\% of CG was associated with $\mathrm{HBV}+$ or $\mathrm{HIV}+$ serology. Mixed CG were found in $25.4 \%$ of patients with anti dsDNA, anti-SSA60 or anti-CCP autoantibodies $(\mathrm{Ab})$. Mixed CG were positive for $87 / 333$ (26.1\%) patients with anti-dsDNA Ab, 74/447 (16.6\%) patients with anti-SSA60 Ab, and for 19/155 (12.3\%) patients with anti-CCP $\mathrm{Ab}$. Both the cryoprecipitate and the serum were positive for RF in $21.6 \%$ of type II CG and $10.1 \%$ of type III CG. C3, C4 and/or CH50 decrease was found in $23.6 \%$ of serum with CG vs $3.2 \%$ of CG-negative serum $(\mathrm{p}<0.001)$.

Conclusions In this largest cohort even studied, with patients from all clinical specialties, CG distribution and characteristics were described with minimal selection bias. Despite strict preanalytical conditions, negative CG detection must be repeated according to clinical context. Mixed CG are more frequently detected in patients positive for HCV or anti-dsDNA Ab. CG with RF activity form immune complexes that precipitate in vessels and activate complement system, responsible for cryoglobulinemic vasculitis.

Disclosure of Interest None declared.

\section{P042/005 MOLECULAR MIMICRY AND AUTOIMMUNITY: ANTI-P. GINGIVALIS ANTIBODY RESPONSE IN ACPA-POSITIVE RHEUMATOID ARTHRITIS}

${ }^{1} \mathrm{~N}$ Sherina*, ${ }^{1} \mathrm{~N}$ Sippl, 'L Israelsson, ${ }^{1} \mathrm{E}$ Le Maitre, ${ }^{1} \mathrm{~N}$ Kharlamova, ${ }^{1} \mathrm{M}$ Hansson, ${ }^{2} \mathrm{~K}$ Eriksson, ${ }^{2} \mathrm{~T}$ Yucel-Lindberg, ${ }^{1} \mathrm{~V}$ Malmström, ${ }^{1} \mathrm{~K}$ Amara, ${ }^{1} \mathrm{~K}$ Lundberg. ${ }^{1}$ Department of Medicine; ${ }^{2}$ Department of Dental Medicine, Karolinska Institutet, Stockholm, Sweden

\subsection{6/annrheumdis-2018-EWRR2019.34}

Career situation of first and presenting author Student for a master or a $\mathrm{PhD}$.

Introduction The presence of anti-citrullinated protein antibodies (ACPAs) is a hallmark of rheumatoid arthritis (RA). ACPAs specifically recognize citrullinated epitopes, a result of a posttranslational modification catalyzed by peptidyl arginine deiminases (PAD). Based on the unique feature of the periodontal bacteria Porphyromonas gingivalis (P.gingivalis) to express $P$. PAD it has been suggested that ACPA-positive RA may be precipitated in the gum mucosa.

Objectives To address this hypothesis our aims were to investigate the antibody response against a citrullinated P.PAD peptide (CPP3) in patients with RA, chronic periodontitis (PD) and in controls. In addition, we generated monoclonal antibodies (mAbs) from gingival tissue $B$ cells of RA patient aiming to investigate whether citrulline-specific B cells may reside in the gingiva.

Methods Gingival tissue-derived single CD19+ B cells from an ACPA-positive RA patient with PD were sorted by flow cytometry. Immunoglobulin variable region genes were sequenced and expressed to generate recombinant mAbs. CPP3-reactivity was analysed by ELISA in serum samples from 66 PD patients, 63 periodontally healthy controls (non-PD), 200 RA patients, and 120 non-RA controls, as well as in 55 mAbs. Differences in antibody levels were examined using Mann-Whitney $U$ test for independent groups.

Results Anti-CPP3 antibody levels were low in non-PD controls, while $65 \%$ of PD patients showed elevated levels $(p<0.0001)$. Significantly increased antibody levels were also 